Studia z Filologii Polskiej

i Słowiańskiej, 46

SOW, Warszawa 2011

Iwona Kaproń-Charzyńska

\title{
Funkcja stylistyczna formantów słowotwórczych. Zarys problematyki
}

Celem artykułu jest zasygnalizowanie niektórych problemów związanych z wyróżnianiem i badaniem funkcji stylistycznej formantów słowotwórczych. Podejmowane są w nim kolejno następujące zagadnienia: funkcja stylistyczna formantów w kontekście funkcji formantów wyróżnianych w strukturalistycznych i poststrukturalistycznych opisach słowotwórczych, problemy w ustalaniu wartości stylistycznych typów i formantów słowotwórczych, narzędzia, które mogą być wykorzystane w badaniu tych wartości.

Zagadnienie funkcji formantów słowotwórczych jest poruszane w opracowaniach z zakresu słowotwórstwa synchronicznego. Formalnym wykładnikom pochodności słowotwórczej przypisuje się określone funkcje, które są podstawą klasyfikacji derywatów. W literaturze przedmiotu można znaleźć kilka takich propozycji. Zasadniczo nie wyróżnia się w nich funkcji stylistycznej formantów słowotwórczych, por. klasyfikacje przedstawione przez R. Laskowskiego (1966), M. Honowską (1967) i R. Grzegorczykową (1972).

Najbardziej rozpowszechniona w polskim słowotwórstwie opisowym koncepcja funkcji formantów, zaprezentowana przez szkołę warszawską (Grzegorczykowa, Puzynina 1979, 28-32), obejmuje następujące funkcje: strukturalną (derywaty tautologiczne), gramatyczną (derywaty transpozycyjne), semantyczną przedmiotową (derywaty mutacyjne) i semantyczną jakościową (derywaty modyfikacyjne). W świetle tej koncepcji funkcja struktural- 
na przysługuje wszystkim formantom, jest obligatoryjna. Poza derywatami tautologicznymi, pozostałe grupy derywatów to takie, w których formanty obok funkcji strukturalnej pełnią przynajmniej jeszcze jedną funkcję. Wśród nich zwraca się uwagę na formacje z wykładnikami pochodności pełniącymi dwie funkcje, nie licząc funkcji strukturalnej, por. derywaty modyfikacyjno-transpozycyjne, np. bieganina, i derywaty mutacyjno-modyfikacyjne, np. modnisia. W „żółtej gramatyce” tego typu leksemy zostały umieszczone w odrębnej grupie derywatów mieszanych (por. Grzegorczykowa, Puzynina 1998, 377).

Od przedstawionej koncepcji funkcji formantów wyraźnie odbiega propozycja S. Grabiasa (1981, 45-53), ponieważ wykracza poza ramy opisu strukturalistycznego (por. Skarżyński 1999, 150). Grabias analizuje formanty będące nośnikami ekspresji. W określaniu ich funkcji posługuje się metodą analizy składnikowej, rzadko wykorzystywanej w słowotwórstwie. Wyróżnia strukturalne, semantyczne oraz pragmatyczne funkcje formantu. Te ostatnie rozumie jako wykładniki relacji zachodzących między wyrazem pochodnym a nadawcą i odbiorcą. Obejmują one komponent modalny (postawa intelektualna polegająca na osadzeniu desygnatu w rzeczywistości), emocjonalny (desygnat jest bodźcem reakcji dodatnich lub ujemnych) i metajęzykowy, o którym autor pisze: „jeśli formant jest odbierany jako wykładnik określonej stylistyczno-socjalnej odmiany języka, to staje się tym samym bodźcem reakcji metajęzykowej" (Grabias 1981, 53).

Ewokację odmian stylistycznych języka przez środki morfemowe S. Grabias umieszcza w obrębie aluzji leksykalnej, czyli zjawiska, które „polega na kierowanym przez nadawcę (a więc celowym i zgodnym $z$ jego intencjami) przywoływaniu zjawisk znaczeniowych związanych $\mathrm{z}$ danym wyrazem, ale pozostających jednak poza znaczeniem leksykalnym" (Grabias 1981, 137). Tak rozumiana aluzja leksykalna jest zawsze procesem metajęzykowym, ewokującym trzy typy zjawisk: a) języki etniczne oraz stylistyczne lub socjalne odmiany języka; b) typy słowotwórcze; c) określone jednostki leksykalne. Różni się tym samym od aluzji na poziomie wypowiedzeń, która ma charakter prawie nieograniczony. Zamierzeniem nadawcy i celowością aluzja leksykalna różni się od innych rodzajów ewokowania. Ewokacja nie musi być zamierzona przez nadawcę; może zachodzić tylko w świadomości odbiorcy. Swoje spostrzeżenia dotyczące ewokowania językowych odmian stylistyczno-społecznych S. Grabias odnosi do grupy 144 formantów ekspresywnych sufiksalnych i alternacyjnych, które mogą przywoływać następujące odmiany języka: polszczyznę ogólną, gwary, polszczyznę potoczną, książkową, żargony i polszczyznę kolokwialną. 
Ustalając, jakie odmiany polszczyzny są ewokowane przez badane formanty, autor odwołał się do własnej, a następnie zbiorowej kompetencji socjolingwistycznej. Z przedstawionej przez niego klasyfikacji formantów wynika, że mówiący dzielą morfemy ekspresywne wyraźnie na dwie grupy: formanty właściwe polszczyźnie mówionej i formanty właściwe polszczyźnie pisanej. Większość formantów, zdaniem badanych, ewokuje cechę kolokwialności, ale tylko w odniesieniu do części z nich udało się ustalić typ kolokwialności, czyli ewokowanie gwar, języka potocznego lub żargonów i slangu. Aż 60 formantów spośród 144 ma, według ankietowanych, zatartą wartość stylistyczno-społeczną. Podsumowując przeprowadzone badania, S. Grabias $(1981,149)$ stwierdza: „Przegląd formantów ekspresywnych, dokonany z punktu widzenia możliwości, jakimi dysponują one w procesie aluzji, prowadzi do wniosku, że formanty te $\mathrm{z}$ trudem poddają się klasyfikacji. Wydaje się, że jedyną, w miarę obiektywną metodą, jaką można stosować przy ustalaniu stylistyczno-socjalnych rozwarstwień na poziomie morfemów, jest badanie zbiorowej kompetencji socjolingwistycznej”.

S. Grabias nie posługuje się pojęciem funkcji stylistycznej formantów słowotwórczych, lecz pojęciem komponentu metajęzykowego (składającego się na funkcję pragmatyczną formantu), o którym można mówić wówczas, gdy formant jest odbierany jako element ewokujący określoną odmianę stylistyczno-socjalną polszczyzny. Przeprowadzone przez niego badanie zbiorowej kompetencji lingwistycznej, opierające się na rozmieszczeniu przez ankietowanych (84 studentów filologii polskiej) formantów ekspresywnych w ustalonych klasach, służyło przypisaniu formantów słowotwórczych do określonej odmiany języka, w rezultacie - przypisaniu im określonej wartości stylistyczno-społecznej ${ }^{1}$.

Druga, wykraczająca poza strukturalizm, klasyfikacja derywatów ze względu na funkcje formantów została zaproponowana przez A. Nagórko (2003a, 225). Proponuje ona wyróżniać trzy funkcje formantu: tekstotwórczą, semantyczną i pragmatyczną. Funkcja pragmatyczna formantu miałaby ujawniać się w tworzeniu derywatów ekspresywnych (pozorne zdrobnienia, augmentatywa, spieszczenia), w indywidualizującej grze językowej, polegającej na reinterpretacji zastanej formy słowotwórczej, także obejmować stylistyczny dobór środków słowotwórczych. Zdaniem A. Nagórko (2003a, 225)

${ }^{1}$ S. Grabias $(1981,144)$ pisze: „Wynik zbiorowej kompetencji okazał się na tyle skomplikowany, że dla przejrzystości obrazu trzeba było przyjąć pewne wyznaczniki upraszczające interpretację materiału. (...) Ponadto wyodrębniła się grupa formantów o zatartej wartości społeczno-stylistycznej” [podkreślenie moje - I. K.Ch]. 
nie trzeba wyodrębniać w opisie modułu stylistycznego, „skoro motywacja stylistycznego doboru środków słowotwórczych ma charakter pragmatyczny". Przedstawione przez nią sytuacje, odnoszące się do stylistycznego doboru środków słowotwórczych, stanowią odzwierciedlenie tych dwóch sytuacji, które E. Zemska (1992, 8-10) wymienia w obrębie stylistycznej funkcji słowotwórstwa: „a) konkurencja zachodzi między podstawą a derywatem różniącym się od niej nie znaczeniem, lecz nacechowaniem pragmatycznym, np. cielę > cielak, kurczę > kurczak (derywaty reprezentują potoczną, mówioną odmianę języka); b) mamy do czynienia z parą derywatów o różnych formantach zróżnicowanych pragmatycznie, np. warszawianin i bardziej potoczne warszawiak, lub (pani) psycholog i potoczne psycholożka lub wyszukane psychologini" (Nagórko 2003a, 225). Oba typy zależności między jednostkami języka, omawiane przez A. Nagórko, mieszczą się w zakresie synonimii leksykalnej (por. Apresjan 1974).

Należy zwrócić uwagę, że zakres pragmatycznej funkcji formantów jest w ujęciu A. Nagórko szerszy niż w ujęciu S. Grabiasa (por. wyżej). Wynika to $\mathrm{z}$ faktu, że autorka w obrębie funkcji formantów słowotwórczych umieszcza także funkcje słowotwórstwa ${ }^{2}$. Nie wprowadza ona pojęcia stylistycznej funkcji formantów słowotwórczych, ale opisywany stylistyczny dobór środków słowotwórczych, podobnie jak S. Grabias, umieszcza w ramach funkcji pragmatycznej formantów. Podporządkowuje w ten sposób stylistykę pragmatyce (tak samo Grochowski 2008, 46-48). Przedstawione przez A. Nagórko przykłady stylistycznego doboru środków słowotwórczych ujawniają inny niż u Grabiasa sposób widzenia zagadnienia. W sytuacji odnoszącej się do par leksemów typu cielę > cielak, kurczę > kurczak mamy do czynienia z jednostkami języka pozostającymi w relacji motywacji słowotwórczej. Żaden z pary wyrazów wchodzących w tę relację nie jest bardziej złożony semantycznie, ale jeden z nich charakteryzuje się większą złożonością formalną i można uznać go za derywat ${ }^{3}$. Formantowi -ak, poza funkcją strukturalną, da się przypisać

${ }^{2} \mathrm{~W}$ artykule pt. Pragmatyczna funkcja formantów $w$ opisie derywatów (Kaproń-Charzyńska 2007) zwróciłam uwagę, że pojęcie pragmatycznej funkcji formantów zaproponowane przez A. Nagórko odnoszone jest z jednej strony do zjawisk, w których rzeczywiście formanty pełnią wymienioną funkcję, np. formanty w derywatach ekspresywnych, np. -isko w psisko, z drugiej zaś do reinterpretacji zastanej formy słowotwórczej, np. odważnik 'człowiek odważny', ekspresywnych kontaminacji i kompozycji. Reinterpretacja zastanej formy słowotwórczej nie jest przykładem realizacji pragmatycznej funkcji formantów, ale określonej funkcji słowotwórstwa.

${ }^{3}$ K. Waszakowa (1994) podaje, że derywat to ten z pary wyrazów, który charakteryzuje się większą złożonością formalną i/lub semantyczną. Może być jednak tak, że w parze 
jeszcze jedną funkcję, którą A. Nagórko określa jako pragmatyczną. Ten rodzaj funkcji formantu można nazwać stylistycznąa ${ }^{4}$ O pełnieniu przez formant wymienionej funkcji nie da się stwierdzić, zestawiając pary wyrazów warszawianin - pot. warszawiak, (pani) psycholog - pot. psycholożka, ponieważ nie zachodzi między nimi stosunek motywacji słowotwórczej. ${ }^{5}$ W literaturze przedmiotu takie pary derywatów są nazywane obocznymi formacjami współpodstawowymi (por. Satkiewicz 1969), dubletami słowotwórczymi, kiedy formacje nie są jeszcze zróżnicowane semantycznie lub stylistycznie (Buttler 1990), synonimami słowotwórczymi (Jadacka 1986; Kaliszan 2000; Szczaus 2005), synonimami pragmatycznymi (Nagórko 2003a). Ich występowanie może być świadectwem zróżnicowania stylistycznego formantów słowotwórczych.

Potrzebę dokładniejszego opracowania problemu pragmatycznych funkcji formantów, zauważonych przez A. Nagórko, widzi T. Kurdyła (2002, 178-187). Wymieniony autor proponuje uzupełnić podział na transpozycję, mutację i modyfikację o dwa typy derywatów - tautologiczne właściwe, np. taksówka $<$ taxi, porfiryt $<$ porfir, i tautologiczne stylowe, np. kompakt $<$ plyta kompaktowa, matma < matematyka, myśliwiec < myśliwy. Ostatnie to takie, w których formant, poza funkcją strukturalną, pełni tylko jedną funkcję przełącza rejestry. Są to więc przykłady odpowiadające u A. Nagórko (2003a, 225) sytuacji zróżnicowania stylistycznego środków słowotwórczych typu cielę > cielak.

leksemów pozostających w relacji motywacji słowotwórczej nie ma różnic semantycznych, a derywatem jest leksem prostszy pod względem formalnym, por. derywaty z formantami ujemnymi i paradygmatycznymi, np. fiza < fizyka, sem < seminarium, manifa < manifestacja, spodzień < spodnie, koszul < koszula. O kierunku pochodności decyduje w takim wypadku „nacechowanie stylistyczne lub emocjonalne, a wyrazem fundowanym jest wyraz nacechowany" (Grabias 1981, 97-98).

${ }^{4}$ Należy zwrócić uwagę, że różnica stylistyczna nie jest jedyną różnicą w analizowanych parach wyrazów. Formant -ak powoduje także przeniesienie derywatu do innego wzorca odmiany rzeczownika.

${ }^{5}$ T. Kurdyła $(2002,180)$ pary akuszeria // akuszerstwo, asceza // ascetyzm, apostolat // apostolstwo, masaż // masowanie, diagnosta // diagnostyk traktuje jako warianty morfologiczne od jednej podstawy. Pisze on: „Zależność znaczeniowa i/lub składniowa pomiędzy nimi jest oczywiście współrzędna (tożsamość znaczenia i/lub funkcji składniowej), nie jest ona jednakże zależnością stricte słowotwórczą, nie ujmuje bowiem tych relacji w stosunek: wyraz motywujący - wyraz motywowany. Obydwa wyrazy są derywowane od innej, wspólnej im podstawy, która wszakże ma różne od nich znaczenia, np. diagnosta // diagnostyk 'ten, kto stawia diagnozę $\leftarrow$ diagnoza (mutacja) bądź funkcję składniową, np. montaż // montowanie 'to, że się montuje' $\leftarrow$ montować (transpozycja)'. 
Jak słusznie zauważa A. Nagórko, wyodrębnienie pragmatycznych funkcji formantów wymaga oddzielenia semantyki od pragmatyki, a to rzecz niełatwa. W strukturalistycznych opisach słowotwórstwa nie oddzielano od siebie dwóch wymienionych obszarów opisu języka, nie uwzględniano w opisie stylistycznej funkcji formantów. Bliższe przyjrzenie się grupie derywatów tautologicznych i uwzględnienie w ich opisie zjawisk mieszczących się w obszarze pragmatyki może doprowadzić do wniosku, iż w dużej części są to derywaty właśnie o funkcji stylistycznej formantów, być może jednocześnie i o innych funkcjach, np. gramatycznych (kiedy zmienia się wzorzec odmiany derywatu w stosunku do podstawy słowotwórczej). Żeby to ustalić, trzeba zbadać formant pod kątem pełnienia przez niego poszczególnych funkcji. W tym kontekście słuszne wydaje się, zaproponowane przez S. Grabiasa, traktowanie formantu jako elementu polifunkcyjnego. Pełnienie przez formant jednej czy kilku funkcji jednocześnie powinno znaleźć odzwierciedlenie w klasyfikacji derywatów ze względu na funkcje formantów ${ }^{6}$.

Badanie funkcji stylistycznych formantów słowotwórczych na tle innych ich funkcji nie jest łatwe. Stwierdzenie, czy jakiś formant pełni funkcję stylistyczną, jest możliwe, jeśli zna się jego wartość stylistyczną i wartość stylistyczną podstaw, z którymi się łączy. Dopiero wówczas można ustalić, czy $\mathrm{w}$ procesie derywacji formant zdeterminował pod względem stylistycznym podstawę słowotwórczą; w konsekwencji, czy za jego sprawą, zmienia się wartość stylistyczna derywatu w stosunku do podstawy. Nie musi tak być. Zapewne są derywaty, które dziedziczą własności stylistyczne podstaw słowotwórczych, są takie, których wartość stylistyczna nie jest dziedziczona, nie jest też wnoszona przez formant, ale jest zupełnie odmienna. W tym ostatnim wypadku podstawa słowotwórcza i formant bardzo różnią się pod względem stylistycznym, a zderzenie tych różnic $\mathrm{w}$ derywacie jest źródłem ekspresji, por. dętologia, łopatologia (Buttler 2001, 156), czapencja, włosencje, pralencja (Kaproń-Charzyńska 2009, 63).

Jak wiadomo, nie wszystkie środki języka są nacechowane stylistycznie. Jeżeli ograniczyć obserwację do zasobu leksykalnego, można wskazać w jego obrębie leksemy neutralne oraz leksemy nacechowane stylistycznie. Pierwsze mogą być użyte $\mathrm{w}$ wypowiedzi formułowanej w każdym stylu, niezależnie

${ }^{6} \mathrm{~W}$ obrębie szkoły warszawskiej hierarchizowało się funkcje formantów, co przekładało się na klasyfikację derywatów ze względu na te funkcje. W efekcie derywaty z formantami o funkcji semantycznej przedmiotowej, bez względu na to, czy pełniły jeszcze jakąś funkcję, czy też nie, klasyfikowane były jako derywaty mutacyjne (por. Kaproń-Charzyńska 2005, 19-26). 
od sytuacji ${ }^{7}$ drugie natomiast reprezentują określony styl, co nie oznacza, że muszą być wykorzystane zgodnie $\mathrm{z}$ tą reprezentacją. Używając wyrażenia w danej sytuacji, mówiący dokonuje różnych wyborów. Wybór stylistyczny - ze względu na cel wypowiedzi, w której ma być realizowana inna funkcja niż komunikatywna - jest jednym $\mathrm{z}$ nich ${ }^{8}$. Określenie wartości stylistycznej środków językowych, ocena celowości i skuteczności ich użycia to zagadnienia kluczowe dla stylistyki, a więc szerzej - dla pragmatyki. Do tych środków należą także formanty słowotwórcze.

Wartość stylistyczna typów i formantów słowotwórczych, zwłaszcza rzeczownikowych, była w przeszłości przedmiotem zainteresowania badaczy (por. np. Kurkowska, Skorupka 1959; Satkiewicz 1969; Grzegorczykowa, Puzynina 1979; Grabias 1981; Waszakowa 1994, 2005; Jadacka 2001; Nagórko 2003b, 2003c; Lubaś 20039). Mimo to istnieje potrzeba prowadzenia dalszych badań w tym kierunku. Potrzeba ta wynika nie tylko $\mathrm{z}$ nieuwzględnienia $\mathrm{w}$ istniejących opracowaniach całości materiału językowego, ale także z konieczności weryfikacji dotychczasowej wiedzy.

H. Kurkowska i S. Skorupka (1959, 53-54) opisują formant -ak (por. cielak, tępak, równiak) jako odznaczający się wyraźną barwą środowiskową, a wtórnie także emocjonalną. Autorzy podają przyczynę ekspresywności wymienionego formantu - występowanie w uniwerbizmach (np. przystojniak 'człowiek przystojny') i wartość emocjonalna, która, ich zdaniem, jest różnorodna oraz zależna „i od semantycznej wartości tematu wyrazowego, i od środowiska, które danego wyrazu używa” (Kurkowska, Skorupka 1959, 53) ${ }^{10}$. Jeżeli weźmie się pod uwagę derywaty przystojniak, równiak, porządniak, i derywaty ciemniak, ponurak, smętniak, sztywniak, to nietrudno oprzeć się wrażeniu, że nacechowanie dodatnie trzech pierwszych i ujemne kolejnych jest

${ }^{7}$ A. Markowski (1992) nazywa takie słownictwo „wspólnoodmianowym”.

${ }^{8}$ Oprócz wyboru stylistycznego wyróżnić można wybór socjolektalny, wynikający z przynależności mówiącego do danej grupy (zawodowej, środowiskowej, pokoleniowej, terytorialnej) oraz wybór psychofizjologiczny, wynikający z etapu rozwoju osobniczego człowieka (por. Grochowski 2008, 47-48).

${ }^{9} \mathrm{Na}$ przykład H. Satkiewicz $(1969,21-55)$, opisując nazwy wykonawców czynności i nazwy nosicieli cech, przypisuje formantom -acz, -ec, -owiec, -owy charakter neutralny, np. rozrabiacz, trzepacz, wodociagowiec, świetlicowy, derywatom z formantem -arz - charakter potoczny lub środowiskowy, np. delfiniarz, młociarz, płotkarz, formantom -ka, -ówka i derywatom z tymi formantami - charakter środowiskowy, np. ubraniówka, kreskówka, podstawówka.

${ }^{10}$ Inaczej H. Satkiewicz $(1969,55)$, która derywatom $\mathrm{z}$ formantem -ak przypisuje silne zabarwienie emocjonalne i przynależność do warstwy potocznej języka ogólnego, graniczącej $\mathrm{z}$ wiechem, samemu zaś formantowi - funkcję ekspresywną związaną z jego pochodzeniem gwarowo-miejskim, por. ostrożniak, przeciętniak, ważniak, starszak, ogólniak. 
uzależnione od nacechowania podstawy słowotwórczej. Wymienieni autorzy, omawiając możliwości stylistyczne typów i formantów słowotwórczych, nie oddzielają wyraźnie własności formantów od własności podstaw, z którymi formanty się łączą. Wydaje się, że przypisywanie przez nich wartości emocjonalnej formantowi - ak wynika $\mathrm{z}$ przeniesienia wartości podstawy słowotwórczej na formant. Ci sami autorzy w rozdziale pt. Wartość stylistyczna form morfologicznych (por. Kurkowska, Skorupka 1959, 44-60) w obrębie tych ostatnich wskazują na formanty tworzące zdrobnienia, zgrubienia oraz na inne przyrostki o odcieniu stylistyczno-emocjonalnym. Według nich, zdrobnienia z formantami -ik/-yk, -ek, -iczek/-yczek, -iszek, -aszek, -uszek, -ka, -yczka, -eńka, -uś, -ula, -ko, -unia oraz zgrubienia z sufiksami augmentatywnymi, z których najbardziej żywotne są: -sko, -isko / -ysko, -idło / -ydło, funkcjonują $\mathrm{w}$ dwu spośród sześciu wymienianych przez nich odmian stylowych polszczyzny - w stylu potocznym i artystycznym. S. Grabias $(1981,146)$ formanty melioratywne $-e k,-i k,-k a$, -nia oraz formanty pejoratywne $-b a$, -idło, -isko klasyfikuje w obrębie formantów przywołujących polszczyznę ogólną. Autorzy Stylistyki polskiej w stylu potocznym umieszczają także derywaty z formantem - aj (formant wnosi zabarwienie pogardliwe, por. mazgaj), natomiast u S. Grabiasa ten sam formant występuje w obrębie formantów przywołujących żargony i slang. Zdaniem H. Satkiewicz $(1969,60)$ derywaty $z$ formantem -owicz mają charakter żartobliwy, swobodny i, w odróżnieniu od struktur na -arz, należą do leksyki języka literackiego, nie mają charakteru środowiskowego, por. działkowicz, kadrowicz. Z kolei H. Kurkowska i S. Skorupka (1959, 53) przyrostkom -owicz i -ewicz przypisują charakter potoczny i żartobliwy.

Przyczyną różnic interpretacyjnych u poszczególnych autorów może być fakt, że niektórzy z nich dążą do ustalenia wartości stylistycznej formantów, inni określają wartość stylistyczną derywatów z tymi formantami. To, że obserwacji poddawane są różne obiekty, nie ma znaczenia tylko wówczas, gdy formant determinuje pod względem stylistycznym podstawę. Drugim elementem, na który trzeba zwrócić uwagę, są narzędzia, jakimi poszczególni autorzy posługują się, określając wartość stylistyczną typów i formantów słowotwórczych. Badacze odwołują się do swojej intuicji językowej i/lub korzystają z ustaleń zawartych w słownikach (por. np. Kurkowska, Skorupka 1959, 125; Satkiewicz 1969, 7; Grabias 1981, 9; Grzegorczykowa, Puzynina $1979,51)$.

Opieranie się na własnym poczuciu językowym w opisie naukowym, który powinien być obiektywny, można by ocenić negatywnie, gdyby nie jego przyczyny. Tak przedstawiła je ponad czterdzieści lat temu H. Satkiewicz (1969, 7): „Klasyfikacja przykładów z tego punktu widzenia [pochodzenia wyrazów 
z określonej odmiany funkcjonalnej języka - uzup. moje - I. K.Ch.] sprawia najwięcej trudności, przede wszystkim ze względu na charakterystyczne dla współczesnej polszczyzny fluktuacje między poszczególnymi stylami. Ponadto badania nad zróżnicowaniem funkcjonalno-stylistycznym języka są w chwili obecnej w stadium początkowym. Rozstrzyganie więc o przynależności tego lub innego neologizmu do określonej odmiany stylowej ma w wielu wypadkach charakter subiektywny, trzeba się z konieczności opierać na własnym poczuciu językowym". Wydaje się, że pierwsza z przyczyn podanych przez autorkę, czyli fluktuacje między stylami, ma charakter ponadczasowy i wynika, mówiąc najogólniej, z czegoś, co można by nazwać „życiem języka” (por. np. Satkiewicz 2000; Warchoł-Schlottmann 2004). Druga przyczyna może wyjaśniać różnice interpretacyjne pomiędzy ujęciami, które są odległe czasowo. Żeby stwierdzić, czy odnosi się ona także do współczesności, trzeba by ocenić stopień zaawansowania badań nad zróżnicowaniem funkcjonalno-stylistycznym polszczyzny. Ocena taka z pewnością nie jest łatwa, zwłaszcza jeśli miałaby być rzetelna. $Z$ jednej strony, nie ulega wątpliwości, że od czasu ukazania się wspomnianej książki H. Satkiewicz, pojawiły się nowe propozycje, odnoszące się do wymienionego wyżej obszaru badań ${ }^{11}$. Z drugiej strony, językoznawcy zwracają uwagę, że różnorodność tych propozycji, wynikająca z przyjmowania różnych kryteriów podziału, a dalej z różnego stopnia jego szczegółowości, nie wpływa korzystnie na opis zjawisk językowych ${ }^{12}$.

Odbicie opisywanego stanu rzeczy znajdujemy także w słownikach jednojęzycznych, które są dla użytkowników języka głównym źródłem informacji o niesemantycznych właściwościach jednostek języka. Informacje te są przekazywane za pomocą kwalifikatorów, przedstawianych we wstępach do słowników. P. Żmigrodzki (2005, 69-70) podaje cztery postulaty, związane z użyciem kwalifikatorów w opisie leksykograficznym: 1. kwalifikato-

${ }^{11}$ Por. np. Furdal (1973), Grabias, Skubalanka (1979, 29-60), Buttler (1982), Gajda (1982, 2001), Markowski (1992), Wilkoń (2000).

${ }^{12}$ M. Grochowski $(2008,49)$ pisze: „W klasycznym strukturalizmie praskim (B. Havránek) wyodrębniano cztery podstawowe style funkcjonalne: potoczny, zawodowy, naukowy i poetycki. Współcześnie poszczególni badacze wysuwają z reguły autorskie propozycje typologii stylów, w porównaniu z koncepcjami klasycznymi bardzo szczegółowe i wielopoziomowo rozbudowane. Na ogół autorski jest także sposób interpretacji terminów służących charakterystyce stylów, co znajduje wyraz w opisach jednostek leksykalnych nacechowanych stylistycznie (pragmatycznie)”. Z kolei D. Zdunkiewicz-Jedynak (2008, 35), po przedstawieniu kilku klasyfikacji odmian polszczyzny, stwierdza: „Różne systemy klasyfikacyjne dowodzą nie tylko zamętu metodologicznego w tym obszarze stylistyki, ale również zróżnicowania terminów na określenie poszczególnych odmian”. 
ry powinny tworzyć logiczny i rozłączny system, 2 . ich siatka powinna być kompletna, 3. zakres poszczególnych kwalifikatorów powinien być ściśle wyznaczony i zdefiniowany, 4. należy je stosować konsekwentnie do wszystkich jednostek o określonym nacechowaniu lub pochodzeniu. Następnie stwierdza: „Analizy wykazują, że żaden $\mathrm{z}$ tych warunków nie jest spełniony w sposób doskonały. Szczególnie brak zdefiniowania kwalifikatorów; autorzy słowników przyjmują, iż poszczególne określenia (np. uczniowski, książkowy) będą rozumiane przez odbiorców intuicyjnie lub też zgodnie z objaśnieniami odpowiednich leksemów, zamieszczonymi w części hasłowej" (Żmigrodzki 2005, 70). Z kolei M. Grochowski $(2008,49)$ zwraca uwagę, że: „W niektórych słownikach wyróżnia się explicite kwalifikatory stylistyczne jako jeden z typów kwalifikatorów słownikowych, nie są jednak podawane żadne kryteria ich wyodrębniania, nie są również wyjaśniane różnice między typami kwalifikatorów”. Jako przykłady takich słowników Grochowski podaje: Słownik języka polskiego, red. M. Szymczak, Warszawa 1978-1981, Słownik współczesnego języka polskiego, red. B. Dunaj, Warszawa 2006, Uniwersalny słownik języka polskiego, red. S. Dubisz, Warszawa 2003, Wielki słownik frazeologiczny języka polskiego P. Müldnera-Nieckowskiego, Warszawa 2003. Zwraca też uwagę, że wśród 53 kwalifikatorów pragmatycznych, zastosowanych w Dystynktywnym słowniku synonimów A. Nagórko, M. Łazińskiego, H. Burkhardt, Kraków 2004, również nie wyodrębniono kwalifikatorów stylistycznych (por. Grochowski 2008, 49, 51).

Na zakończenie warto byłoby spróbować odpowiedzieć na pytanie: jak badać właściwości stylistyczne formantów słowotwórczych? Niewątpliwie, w ustalaniu tych właściwości nie można opierać się wyłącznie na własnej intuicji językowej. W miarę obiektywną metodą byłoby przeprowadzenie badań ankietowych. Wydaje się, że badania takie powinny być przeprowadzane na poziomie leksemów, a nie formantów słowotwórczych ${ }^{13}$. W tym celu należałoby podawać $\mathrm{w}$ ankiecie leksemy, w których badane formanty występowałyby (w miarę możliwości) w kontekście neutralnych podstaw słowotwórczych. Ponadto konieczne byłoby ustalenie listy kwalifikatorów stylistycznych, które oddawałyby związek między daną jednostką a klasą funkcjonalną wypowiedzi. Można by w tym przedsięwzięciu skorzystać z propozycji A. Bogusławskiego (1973), który przedstawia kategoryzację pragmatyczną jednostek języka,

${ }^{13}$ Należy zwrócić uwagę, że S. Grabias badał wyłącznie morfemy słowotwórcze, a więc tzw. formanty dodatnie. Tymczasem nie jest to jedyny typ formantów. Wydaje się, że przeprowadzenie ankiety dotyczącej właściwości stylistycznych formantów ujemnych wiązałoby się z pewnymi komplikacjami. 
obejmującą ich właściwości akomodacyjne, emotywne, praktyczne i poetyzacyjne. M. Grochowski $(2008,50)$ uznaje, że cechom stylistycznym wyrażeń odpowiadają u Bogusławskiego przede wszystkim właściwości akomodacyjne sytuacyjne, sygnalizowane za pomocą następujących kwalifikatorów: urocz., urzęd., ofic., książk., public., pot., posp., ordyn., eufem., być może także inne, np. poetyzacyjne, por. kwalifikatory: arch., hiper., iron., obr., ret.-pyt., żart. W przyporządkowywaniu kwalifikatorów określonym derywatom mogłoby badaczowi pomóc odwołanie się do Słownika frekwencyjnego polszczyzny współczesnej, red. Z. Saloni, Kraków $1990^{14}$. Należałoby także rozważyć wykorzystanie metody testowo-introspektywnej, którą stosuje np. A. Markowski dla wyodrębnienia leksyki wspólnoodmianowej. W metodzie tej przynależność wyrazów do odmian leksykalnych jest sprawdzana za pomocą testów - schematów zdań (por. A. Markowski 1992, I 29-39).

Ustalenie wartości stylistycznej formantów słowotwórczych to pierwszy, a zarazem niezbędny krok prowadzący do wykrycia funkcji stylistycznych tych formantów.

\section{Literatura}

Apresjan J., 1974, Leksiczeskaja semantika. Sinonimiczeskije sriedstwa jazyka, Moskwa.

Bogusławski A., 1973, Właściwości pragmatyczne wyrażeń równoznacznych. Projekt schema$t u$, „Pamiętnik Literacki” LXIV, z. 3, s. 121-151.

Buttler D., 1982, Miejsce języka potocznego wśród odmian współczesnej polszczyzny, [w:] Język literacki i jego warianty, red. S. Urb a ń c zyk, Wrocław - Warszawa - Kraków - Gdańsk - Łódź, s. 17-28.

Buttler D., 1990, Wahania formy wyrazów zapożyczonych i ich derywatów, „Poradnik Językowy" 4, s. 311-315.

Buttler D., 2001, Polski dowcip językowy, Warszawa.

Furdal A., 1973, Klasyfikacja odmian współczesnego języka polskiego, Wrocław.

Gajda S., 1982, Podstawy badań stylistycznych nad językiem naukowym, Warszawa - Wrocław. Gajda S., 2001, Funkcjonowanie współczesnej polszczyzny, [w:] Najnowsze dzieje języków słowiańskich. Język polski, red. S. Gajda, Opole, s. 207-219.

Grabias S., 1981, O ekspresywności języka, Lublin.

Grabias S., Skubalanka T., 1979, Społeczne uwarunkowania stylów języka, „Socjolingwistyka" 2, s. 29-60.

Grochowski M., 2008, Stylistyka leksykalna jako dział leksykologii i pragmatyki, [w:] Stylistyka a leksykologia. Związki, zależności, metody, red. K. Maćkowiak, C. Piątkowski, Zielona Góra, s. 45-55.

Grzegorczykowa R., 1972, Zarys słowotwórstwa polskiego, Warszawa.

${ }^{14}$ Szerzej na ten temat w: Grochowski 2008, 53-54. 
Grzegorczykowa R., Puzynina J., 1979, Słowotwórstwo współczesnego języka polskiego. Rzeczowniki sufiksalne rodzime, Warszawa.

Grzegorczykowa R., Puzynina J., 1998, Problemy ogólne słowotwórstwa, [w:] Gramatyka współczesnego języka polskiego. Morfologia, red. R. Grzegorczykowa, R. Laskowski, H. Wróbel, Warszawa, s. 361-388.

Honowska M., 1967, Zarys klasyfikacji polskich derywatów, Wrocław.

Jadacka H., 1986, Synonimia słowotwórcza - perspektywy badawcze, „Poradnik Językowy”, z. 6, s. 404-412.

Kaliszan J., 2000, Synonimia słowotwórcza rzeczowników w języku polskim i rosyjskim, Poznań.

Kaproń-Charzyńska I., 2005, Derywacja ujemna we współczesnym języku polskim. Rzeczowniki i przymiotniki, Toruń.

Kaproń-Charzyńska I., 2007, Pragmatyczna funkcja formantów w opisie derywatów, „Biuletyn Polskiego Towarzystwa Językoznawczego", s. 147-156.

Kaproń-Charzyńska I., 2009, O formancie -encja we współczesnej polszczyźnie, „Slavia Meridionalis" 9, s. 60-70.

Kurdyła T., 2002, Luksus słowotwórczy, czyli o tzw. derywatach tautologicznych i funkcjach tworzących je formantów, „Język Polski” LXXXII, z. 3, s. 178-187.

Kurkowska H., Skorupka S., 1959, Stylistyka polska. Zarys, Warszawa.

Laskowski R., 1966, Słowotwórstwo rzeczowników w dialektach laskich, Cz. I: Abstracta, collectiva, deminutiva, augmentativa, Wrocław.

Lubaś W., 2003, Polskie gadanie. Podstawowe cechy i funkcje potocznej odmiany polszczyzny, Opole.

Markowski A., 1992, Leksyka wspólna różnym odmianom polszczyzny, t. 1-2, Warszawa.

Nagórko A., 2003a, Zarys gramatyki polskiej, Warszawa.

Nagórko A., 2003b, Tendencje w sferze pragmatyczno-stylistycznej, [w:] Komparacja współczesnych języków słowiańskich. Słowotwórstwo / Nominacja, red. I. Ohnheiser, Opole, s. $189-97$.

Nagórko A., 2003c, Różnicowanie i unifikacja środków słowotwórczych w służbie pragmatyki, [w:] Komparacja współczesnych języków słowiańskich. Słowotwórstwo / Nominacja, red. I. Ohnheiser, Opole, s. 217-33.

Satkiewicz H., 1969, Produktywne typy słowotwórcze wspótczesnego języka ogólnopolskiego, Warszawa.

Satkiewicz H., 2000, Neutralizacja nacechowania stylistycznego i ekspresywnego w słownictwie współczesnej polszczyzny, [w:] Słownictwo współczesnej polszczyzny w okresie przemian, red. J. Mazur, Lublin.

Skarżyński M., 1999, Powstanie i rozwój polskiego słowotwórstwa opisowego, Kraków.

Szczaus A., 2005, Rzeczownikowe synonimy słowotwórcze w polszczyźnie XVI w., Szczecin.

Warchoł-Schlottmann M., 2004, Ekspansja wyrażeń potocznych do języka oficjalnego, „Poradnik Językowy", z. 4, s. 31-42.

Waszakowa K., 1994, Słowotwórstwo współczesnego języka polskiego. Rzeczowniki sufiksalne obce, Warszawa.

Waszakowa K., 2005, Przejawy internacjonalizacji w słowotwórstwie współczesnej polszczy$z n y$, Warszawa.

Wilkoń A., 2000, Typologia odmian językowych współczesnej polszczyzny, Katowice. 
Zdunkiewicz-Jedynak D., 2008, Wykłady ze stylistyki, Warszawa.

Zemska E.A., 1992, Słowoobrazowanije kak diejatielnost', Moskwa.

Żmigrodzki P., 2005, Wprowadzenie do leksykografii polskiej, Katowice.

\section{Stylistic function of word-formation formants. An outline}

\section{(Summary)}

In the first part of the article, the functions of formants distinguished in the selected structural and post-structural classification of derivatives are presented. In connection with the description of the stylistic function of formal indices of the word-formation origin, the proposal made by S. Grabias (1981) and A. Nagórko (2003c) is discussed in a more expanded aspect. The both authors raise the issue of the stylistic differentiation of word-formation means in the area of the pragmatic function of formants. Due to the fact that the establishment whether the formant is fulfilling the stylistic function, is connected, among others, with the knowledge about its stylistic value, the second part of the article draws up attention to the interpretation differences, which are frequent in the literature, which interpretation differences refer to the stylistic value of certain word-formation formants and word-formation types. The author makes an attempt to discover the reason for the said differences. At the end of the article, the methods, which may be used in the research of the stylistic properties of word-formation formants, are specified. 